\title{
Church Historical Collections in Liberal Arts Colleges
}

\begin{abstract}
A segment of American history is buried in the records of churches and denominations. Church related, liberal arts college libraries are in a position to collect and preserve the historical materials and archives of their church body. Based on the literature on the subject and questionnaires sent to sixty-eight church related liberal arts college libraries with church historical collections, this paper is a discussion of the types of material collected, cataloging and preservation procedures used, circulation and control methods, and housing facilities for a church historical collection.
\end{abstract}

$\mathrm{T}$ HE HISTORY of an important segment of American life is buried in the records of individual churches and of denominations. Students of social and economic history, as well as students of the history of religion, find that church records are gold mines of information. ${ }^{1}$ Some groups are actively engaged in preserving this history by designating their church college libraries as the collection agencies for archival and historical materials. This paper is a study of church history collections housed in the church related liberal arts college libraries of their supporting churches. Four aspects of the collections were studied: (1) the types of materials collected; (2) how these were cataloged; (3) the methods of preservation used; and (4) the methods by which they

${ }^{1}$ M. E. Deutrich, "American Church Archives," American Archivist, XXIV (October 1961), 390.

Miss Luesing is Librarian of Bethel College, Mishawaka, Indiana. This paper is based upon a thesis submitted in partial fulfillment of the degree Master of Arts in Indiana University. were circulated and made available for study and research.

In all of the literature searched, no similar study was located. Three articles were found on the subject of church archives, but none dealt specifically with the problems this paper proposes to study.

To supplement materials gleaned from the printed literature and to ascertain actual practices in libraries having church historical collections, a questionnaire was sent to sixty-eight college librarians. These sixty-eight schools were listed in the ninth edition of American Universities and Colleges prepared by the American Council on Education, 1964. Each school was designated as a liberal arts college, related to a church, and having church historical materials in its collection. This list was compared with the list of colleges and universities in the Yearbook of American Churches, 1964. These lists were compared to ascertain whether all colleges and universities listed in the Yearbook of American Churches as denominational schools 
were also listed in the American Universities and Colleges. No school listed in one was omitted from the other. Thus, it is fairly certain that no church body having a church historical collection housed in a liberal arts college has been overlooked in the study.

Of the sixty-eight questionnaires mailed, fifty-seven or 83.8 per cent have been returned. Of this number, nine had no answers to the questions. One librarian stated that he did not have the time required to prepare answers; the others responded with a letter explaining that their materials were not cataloged or organized in any way, and thus they were unable to fill out the questionnaires. Therefore, the total return with answers was forty-eight, or 70.6 per cent of the sixty-eight.

The final step in the research was to visit a number of libraries having church historical and archival collections. Seven libraries, approximately 10 per cent, of the libraries which received questionnaires were visited. In each case, the person in charge of the collection was interviewed and the collection was briefly surveyed.

From these three sources: the literature available on the subject, the questionnaires sent to sixty-eight librarians, and the personal visits to seven libraries, the following information has been gathered.

Early in the research, it became necessary to define "archives" and "historical collection" for these terms deal with two distinct types of library material. Among possible definitions of the term "archives" are the following: "The term archives... is meant to include semi-official documents, personal memoirs, diaries, photographs, microfilm, and phonograph records." Solon J. Buck states that "the word 'archives' connotes a body of re-

\footnotetext{
${ }^{2}$ C. Lynch, "Archives, Our Responsibility to Posterity," Benedictine Review, X (July 1955), 40.
}

lated documents that, because of their possible evidential value, are preserved as records by the agency that created or received them or by its legitimate successor." ${ }^{3}$ It is only necessary that they be officially preserved for their evidential value as a part of the body of records of some organization. ${ }^{4} \mathrm{~A}$ less complex definition was given by Nelson Springer of Goshen College. He stated that archives "are those nonlibrary materials and nonpublished items"5 in the collection.

On the other hand, the materials classed as the "historical collection" are "published materials that have library usage." 6 For this study, the term "church history collection" is meant to include both archives and the historical collection. Both published materials and the large body of original documents, minute books, etc., are considered necessary in building a church history collection that will be adequate for research.

\section{Materials Included in Church History Collections}

The first task facing the librarian who is beginning a church historical collection is to determine what types of material will be collected. As a general principle, the scope of any church history collection should be neither too broad nor too narrow, but should be oriented primarily to the group it proposes to serve. The sponsoring denomination has the right to expect the depository to meet the needs of that particular church body. ${ }^{7} \mathrm{H}$. Lindley writes in an article in the Library Journal that the historical library is "primarily concerned with: (1)

\footnotetext{
'S. J. Buck, "Let's Look at the Record," American Archivist, VIII (April 1945), 111.

Ibid.

${ }^{5}$ Stated by Nelson Springer in an interview with Lois Luesing at Goshen College, Goshen, Indiana, on November 24, 1964.

"Ibid.

"A. R. Suelflow, "The Struggle of Church Archives for Respectability," American Archivist, XXIV (October 1961), 405.
} 
the book; (2) the pamphlet; (3) the newspaper; (4) the periodical; (5) the map; (6) the broadside; (7) the manuscript; (8) the archive; (9) the picture." 8

A number of problems present themselves as one endeavors to build a church history collection. What out of the vast quantities of material shall be saved? There is, first, an imposing array of minute books; minutes of general conference, districts, and/or regions, and of state bodies; minutes of organizations within the denomination; and minutes of organizations within the local congregation. Then there are registers of birth, marriage, and death for individual churches, treasurer's reports, histories of local churches, and a great quantity of personalia, that is, diaries, correspondence, files, and sermon notes. ${ }^{9}$

There is also the real danger that those in the church will look on this depository as a museum to save their meaningful keepsakes. Pascal Marie Varieur in an article in the American Archivist says "we should not limit ourselves to written or photographic history of our denomination, but we should capture part of the 'artifact-ive' history as well. . . . Let us remember that these artifacts, or museum pieces, are truly records of the past and therefore worthy of our attention."10 Some objects will no doubt find their way to the church history collection, and those having true historical significance belong there. Mr. Suelflow suggests that commemorative medallions, coins, medals, and other museum pieces have a rightful place in the collection. Paraphernalia used by missionaries, communion vessels, altar furnishings, and other similar items become source materials for research and evaluation of the

\footnotetext{
${ }^{8} \mathrm{H}$. Lindley, "Conserving a Historical Collection?" Library Journal, LXXI (July 1946), 992.

'E. C. Kyte, "Archives of the United Church of Canada," American Archivist, XIII (July 1950), 231.

${ }^{10}$ P. M. Varieur, "The Small, Limited, or Specialized Church Archives," American Archivist, XXIV (October 1956), 454 .
}

church's life. ${ }^{11}$ The important thing would seem to be to have a clearly established policy concerning accepting such articles. $^{12}$ Whatever material is offered to the church historical collection, the librarian should answer the question: "Is there a more logical place for this material?"13 If no one would expect it to be a part of the collection, it probably does not belong there. Storage and display space becomes a problem closely linked to the collection of "museumtype" materials.

Anyone now beginning a collection of materials relating to a church that dates back to another generation will find it difficult to identify individuals in group pictures, to ascertain what group it is, and to discover where and when it was taken. Pictures which remain unidentified are of no real value to the historical collection, although they may provide items of interest for display purposes. Older members of the denomination may be asked to help with picture identification and thus give invaluable aid to those working with the church history collection.

When a conclusion has been reached on the types of material to be collected, how does one go about obtaining it? One of the problems is that old minute books and records have not been properly kept. Or if they have been preserved, it has been done by the individual who took the minutes rather than by the local church, and thus the records are deemed to be a family heirloom rather than church property. ${ }^{14}$ The church with all of its organizations needs to be encouraged to deposit all records, treasurer's reports, membership ledgers, etc.,

11 A. F. Suelflow, op. cit., p. 406-407.

12 Stated by Delena Goodman in an interview with Lois Luesing at Anderson College, Anderson, Indiana, on December 8, 1964.

${ }^{13}$ A. R. Suelflow, op. cit., p. 406.

14 Stated by Nelson Springer in an interview with Lois Luesing at Goshen College, Goshen, Indiana, on November 24, 1964. 
with the college. If any organization or institution of the denomination ceases to exist, all records should come to the depository. ${ }^{15}$ Although Roscoe M. Pierson writes chiefly concerning seminary libraries, the following suggestion is worthy of note:

Advertising in denominational and institutional periodicals has been a profitable way of developing denominational collections. Ads placed in alumni publications usually are fruitful for the seminary librarian of the institution; oft repeated announcements that the library is collecting the books, pamphlets, and periodical articles of alumni is one way that some of the most important collections have been nourished. Similar notices or news stories placed in the denominational weeklies or scholarly journals will be of value in the long run. It has been the experience of many librarians that such announcements pay off in the long run better than they do immediately; they serve primarily to let serious collectors within the denomination know that the collector's institution is seriously interested in the material. The result often is acquisition through wills and bequests from families. ${ }^{16}$

This whole area is a subject about which the church people need to be educated. It will be and is a slow process, and the librarian building a church history collection will need constantly to work at the job.

Further, a working relationship should be sought between the denominational publishing house and the library. The publisher should be encouraged to send depository copies for the historical collection. The librarian needs also to be alert to what is being written and who is writing in the church, for books by church people are often published by other than the denominational pub-

\footnotetext{
${ }^{15}$ Stated by Mrs. Asa Colby in an interview with Lois Luesing at Aurora College, Aurora, Illinois, on December 10, 1964.

${ }_{16}$ R. M. Pierson, "Denominational Collections in Theological Seminary and Church Historical Society Libraries," Library Trends, IX (October 1960), 22526.
}

lisher. ${ }^{17}$ Members of the church who are working on doctoral dissertations should not be forgotten, and copies should be sought for the library.

The college library should be on the mailing lists of the general offices, departments, and state offices of the church. ${ }^{18}$ If the weekly bulletins and/or newsletters are desired from the local congregations, an effort could be made to have the library placed on their mailing lists. Mr. Springer suggested that local congregations be urged to accumulate the bulletins and mail them to the library once a year. ${ }^{19}$

The history of any given church body would not be complete without the records of its day schools, colleges, seminaries, homes for the elderly, etc. However, these materials are sometimes difficult to obtain and difficult to store and catalog. Because of the confidential nature of correspondence and personnel records, for instance, administrators may be loath to give these files to the depository. A working agreement should be sought that will insure that every set number of years, perhaps seven, the files would be deposited. ${ }^{20}$ This same problem will be faced with the collection of minutes of executive committees, etc., of the general or state offices of the church. Church leaders need to feel confident that the librarian in charge of such documents will treat them with care and integrity of the highest caliber.

At Earlham College, files are kept on administrators, faculty members, and alumni. These files include clippings that appear in the local newspapers, articles they have written, pictures, and other

17 Stated by Delena Goodman in an interview with Lois Luesing at Anderson College, Anderson, Indiana, on December 8, 1964.

${ }^{18}$ Stated by Nelson Springer in an interview with Lois Luesing at Goshen College, Goshen, Indiana, on November 24, 1964.

19 Ibid.

${ }^{20}$ Stated by Opal Thornburg in an interview with Lois Luesing at Earlham College, Richmond, Indiana, on February 18, 1965. 
TABLE 1.

Number and Per Cent of Respondents Collecting a Given Type of Material for the Church Historical Collection

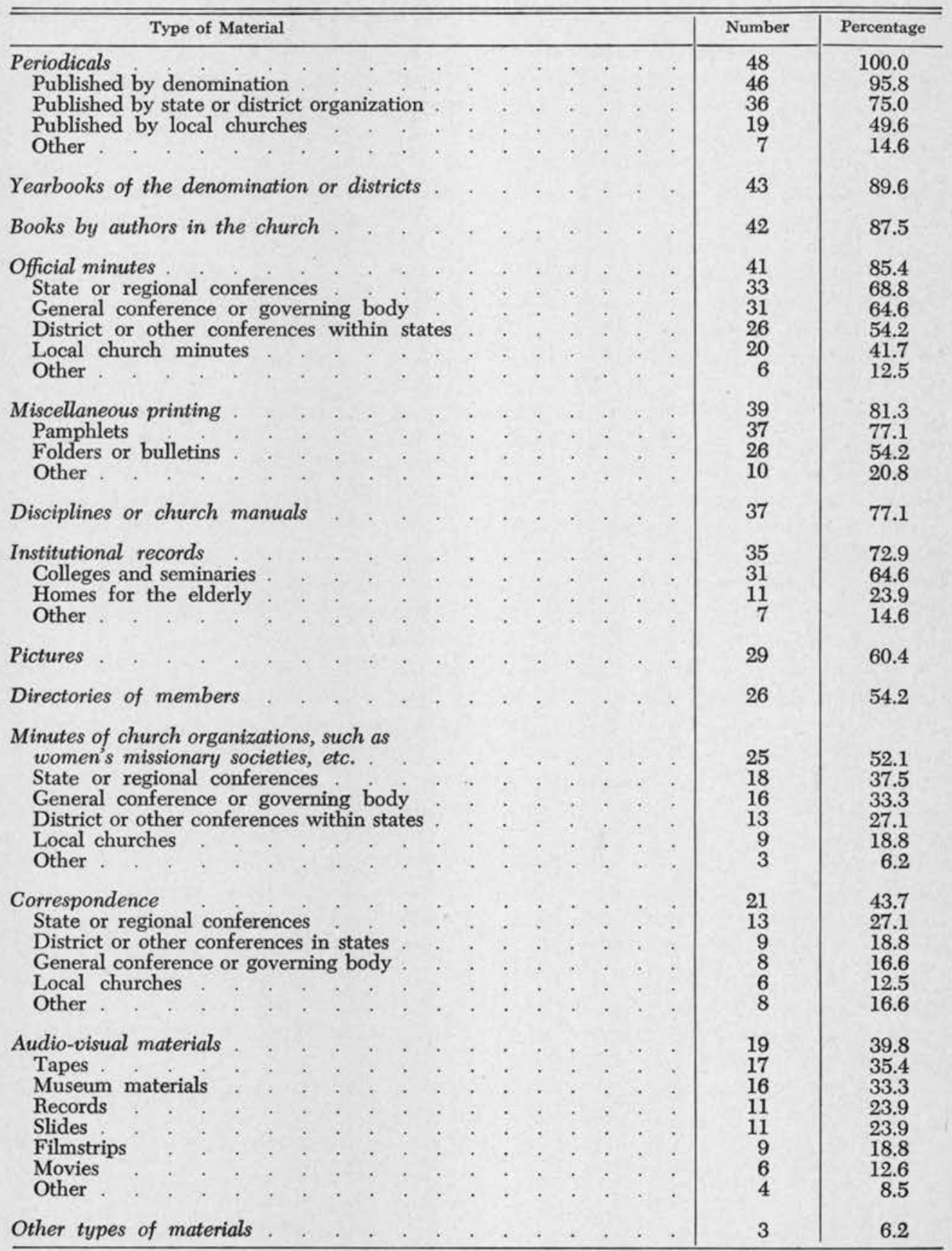


miscellaneous items. ${ }^{21}$ These files bring together much information concerning those individuals who have filled key positions in their churches and colleges.

One might well ask how many copies of books, pamphlets, periodicals, and other printed materials should be kept. There are varying opinions. One suggests a limit of two copies in the collection with a third copy for circulation, ${ }^{22}$ while another suggests one copy for the permanent collection and two for circulation. ${ }^{23}$ Again, the important thing would seem to be to have an established policy that fits the needs of the individual collection. The amount of space allowed for the historical collection within the library will probably be a factor in determining this policy in each given case.

Table 1 gives the responses of fortyeight librarians to the questions on the questionnaire that were related to the types of materials preserved for the church historical collection. Both the number of libraries collecting a given type of material and the percentage of the forty-eight reporting libraries are given. The use of indentation in the table shows the breakdown within the type of material.

It might be noted from the table that the material published by the denomination was collected more frequently than any other type. It is quite obvious that this material is the easiest to acquire. Correspondence and audio-visual materials were collected by the least number of librarians. This material is more difficult to acquire and creates a storage problem.

It was evident from the questionnaires that the larger collections of church materials were those that had the largest variety of materials within the collec-

n Ibid.

2 Stated by Nelson Springer in an interview with Lois Luesing at Goshen College, Goshen, Indiana, on November 24, 1964.

23 Stated by Mrs. Asa Colby in an interview with Lois Luesing at Aurora College, Aurora, Illinois, on December 10, 1964. tion. Those few libraries that had a person especially designated to work in the church historical collection had obviously made the greatest effort to collect more varied materials.

The last item on the table shows that only three types of material other than those previously listed were collected. These items were tracts, term papers, and Sunday School materials. One library had each tract cataloged, and if several had been written by one man, they had been bound as a book. Two librarians mentioned that all Sunday School material was kept. This included quarterlies, teacher's helps, and weekly papers. It was considered important because of the use it might be in planning the curriculum of the Sunday School in the future.

Three librarians indicated that students in the church history class and in seminars were required to deposit their written papers in the historical collection. These were research papers done on subjects relating to the denomination. In one library visited for this study, students had written histories of local churches, biographies of church leaders and missionaries, and histories of certain organizations within the church structure. In this way students were introduced to research from original materials and at the same time made a valuable contribution to the church historical collection.

As new types of material come into being, the librarian in charge of the historical collection should be alert to include these among his acquisitions. There is no limit for the imaginative person who senses the importance of a variety of items to a body of historical materials. In one library, some early costumes were preserved as part of the archives. Any material is in order as long as it relates directly to the history of a church, as long as it is in the plan of the library to collect that type of ma- 
terial, and as long as it does not cause undue storage problems.

\section{Cataloging Procedures}

The first objective of any depository of records is to have adequate control of its record holdings. ${ }^{24}$ To meet this objective, the church historical collection must be cataloged. Not only must the collection be controlled, the material must also be readily available to searchers. ${ }^{25}$ This raises a problem for the librarian who has both archival and historical materials in his collection. Will the records be classified as an archivist would classify them, that is, by organizational body rather than by subject? As a British writer put it, "The librarian classifies and stores his books in accordance with their subject matter; the archivist arranges his documents in accordance with their institutional origin." 26 Of the forty-eight reporting librarians, fifteen organized their material by organizational body and/or administrative unit, thirteen organized by subject, sixteen by a combination of organizational unit and subject, and five made no reply.

While no collection of materials should be made without a simple, organized catalog, ${ }^{27}$ what type of cataloging should be done? If the collection is small, greater emphasis may need to be placed on analyzing the records available. The analysis of material must extend even to the individual document, for there needs to be greater control of every item in the depository. ${ }^{28}$ An increased difficulty in establishing a set of cataloging rules is that the librarian must be familiar with

${ }^{24}$ Sherrod East, "Describable Item Cataloging," American Archivist, XVI (July 1953), 291.

${ }^{25}$ E. G. Campbell, "Functional Classification of Archival Material," Library Quarterly, XI (October 1941), 431.

${ }^{\circ} \mathrm{M}$. Bond, "Archivist and His Records," History Today, XI (July 1961), 502.

${ }^{2}$ W. C. B., "Archives Are Valuable-Provide for Them," Catholic School Journal, LXI (September $1961), 113$.

${ }^{28}$ P. M. Varieur, op. cit., p. 454 the terminology of his particular group and of the literature under his care. Thus, filing systems, subject headings, and inventories will vary from collection to collection. ${ }^{29}$

Accessioning archival and historical materials seems to be the accepted practice. When material is acquired, the first record made of it is in the accession book. This record is usually a brief description of the work, its source, its cost if purchased, and the date of its receipt. $^{30}$ Of the forty-eight returning questionnaires, thirty-three used accession numbers, while twenty-four kept actual accession books.

It is advisable to do temporary cataloging as soon as a new acquisition arrives in the library. A rough main entry card with author, title, place, publisher, and date is essential. A brief-title card may also be made. If the classification number can be assigned quickly, it should be done. This procedure helps eliminate loss of information and the backlogging of material that is waiting to be organized. ${ }^{31}$

When the item is permanently cataloged, each librarian will need to determine how thoroughly it is to be done. The returns on the questionnaire indicated that most librarians cataloging their materials make author, title, subject, and shelflist cards. Of the fortyeight reporting librarians, twenty-two cataloged all materials, nineteen cataloged part of them, and seven did not catalog at all. Of the forty-one librarians cataloging all or part of their material, thirty-seven made author cards, thirtyfive made title cards, thirty-eight made subject cards, twenty-seven made crossreference cards, thirty-five made shelflist cards, and six made cards of other kinds.

A. R. Suelflow, op. cit., p. 405.

${ }^{\circ}$ D. V. Martin, "Use of Cataloging Techniques in Work With Records and Manuscripts," American Archivist, XVIII (October 1955), 318.

s1 Stated by Nelson Springer in an interview with Lois Luesing at Goshen College, Goshen, Indiana, on November 24, 1964. 
Most classification was done according to the Dewey decimal system. Thirtytwo of the forty-eight reporting librarians used the Dewey system; thirteen of that number with modifications. Eight librarians had developed their own system of classification, and four used the Library of Congress system. One librarian classified by the Union theological library system, one used the Lynn-Murphy classification system based on the Library of Congress system with Kapsner Catholic subject headings, and two did not report.

It seems advisable to avoid keeping a special collection separate, for it complicates cataloging and classification as well as storage.

The questionnaire showed that in thirty-two of the forty-eight libraries the regular library cataloger cataloged the church historical collection materials. However, if one person were designated especially for work in the historical collection, or if there were a trained archivist, he usually did his own cataloging.

Involved and difficult as it may be, the cataloging of any church history materials must be undertaken, or the collection is of virtually no value. Each librarian will need to determine by what system the material is to be classified, how detailed the cataloging will be, and where the catalog cards will be filed. Often a separate card catalog is kept in the room with the collection, and a main entry card, at least, is filed in the main library catalog. As Melvin Gingerich of Goshen College writes, "every denominational record collection has its unique features; thus it is impossible to produce a guide that will fit every situation in detail. Nevertheless, church archives have enough in common to make it possible to suggest certain procedures that can be followed in organizing any collection." 32 His article on how to write a guide or manual of procedure would be

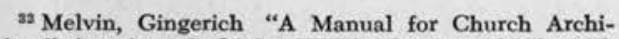
vists," American Archivist, XXIV (October 1961), 445.
}

most helpful to any college librarian involved in the beginning of a church history collection.

\section{Preservation and Housing}

Many of the books and documents that compose a church history collection are either worn with age or misuse or have been exposed to improper light and humidity conditions. The librarian must now protect these materials from further deterioration and provide proper housing conditions to protect new materials against such ravages. In addition to problems caused by excessive heat, light, and humidity, people represent another area of concern for the librarian who has a historical collection under his supervision. Damage to or loss of books and documents is easily caused by the carelessness or thoughtlessness of both staff members and researchers. Thus, preservation includes the control of library materials to the extent of guarding them against misuse, improper handling, and unnecessary marking.

The format of the material many times makes the method of preservation, if not difficult, time consuming and often expensive. Pictures, clippings from magazines and newspapers, broadsides, posters, correspondence, and other single items not only need to be preserved, but need to be preserved in a manner that will make them as easy as possible to file and store. Books are not difficult to store, but torn pages, poor binding, and the type of paper used in the book raise problems that the librarian must recognize.

Mending materials are plentiful and many. However, some work better than others. Those working with the ordinary cellophane mending tapes have found that they not only do not last but they also mar the paper on which they have been used. The "Scotch" brand mending tape has seemed to work well. ${ }^{33}$ It does

\footnotetext{
${ }^{23}$ E. C. Bishop, "Documents-Their Repair and Preservation," American Archivist, XXV (July 1962), 355.
} 
not become brittle and peel off, but on the other hand, it has not been on the market long enough for archivists and librarians to know how it will hold up after years of storage. Mr. Springer suggests the use of plastic adhesive and Japanese tissue for mending tears. ${ }^{34}$

Of the forty-eight responding librarians, fifteen use some type of treatment for preservation of their book materials; nine treat their single documents. Various methods are used on both books and documents.

Broadsides and posters may be protected by placing them on a sheet of heavy bristol or mounting board, laying over them a sheet of cellulose acetate, and binding the edges with masking tape. A single pinhole needs to be provided for "breathing." 35

Single documents may be mounted on sturdy backing for protection and ease in filing. On the forty-eight questionnaires returned, nine librarians stated that they used this method of preservation. One suggested that clippings be mounted on rag content paper, using Elmer's Glue. Two or three others stated that they intended to mount their single pages.

Quik is another good aid for the librarian working on a historical collection. It is a glue solvent that aids in removing old labels and clippings from scrapbooks, etc. ${ }^{36}$ Soiled materials may be cleaned by using a wallpaper cleaner.

Lamination with cellulose acetate foil is recommended by the National Bureau of Standards and has many satisfactory qualities. While it resists bacteria, fungi, and insects, it does not bar photography and is relatively inexpensive. ${ }^{37}$ Of the forty-eight reporting librarians, ten use lamination for preservation. Again, a few

as Stated by Nelson Springer in an interview with Lois Luesing at Goshen College, Goshen, Indiana, on November 24, 1964.

as Bishop, op. cit., p. 355 .

se Ibid.

s7 W. J. Barrow, "Restoration Methods," American Archivist, VI (July 1943), 152. noted that they wanted to do some lamination in the future.

Books, particularly those with leather bindings, need some treatment for preservation. Thirteen of the forty-eight libraries used an oil or lanolin compound on leatherbound books. Some early (sixteenth-century) books were bound in parchment, and saddlesoap is good for these ${ }^{38}$ Every few years books need this attention to keep the bindings soft and pliable.

A few other methods and materials used in preservation were listed on the questionnaires. One library has used the Barrow process for the restoration of documents. This was done by working in cooperation with the department of archives of the state in which the library was located. One librarian used $\mathrm{p}^{\mathrm{H}}$ neutral folders and insert sheets, and another kept materials between acid-free paper. Still another used non-acidic folders and storage boxes. Cellophane and cloth covers were used by one librarian on old minute books.

Because of the damage excessive heat, light, and humidity can cause, the room housing a historical collection should be air-conditioned and humidity-controled. High heat and dryness cause paper to become brittle, while excessive light fades and dries newsprint quickly. Of the forty-eight libraries from which reports were received, twenty-one were air-conditioned; eight of these without humidity control. Librarians in five other schools stated they had humidity control without air-conditioning. One had filtered air with a humidifier and a dehumidifier. Many librarians stated that they recognized the need for such atmospheric conditions in the collection room.

Mold becomes a danger if the air has too much moisture in it, and rag-content paper is especially susceptible to this. For this reason a vault where the air

\footnotetext{
as Stated by Nelson Springer in an interview with Lois Luesing at Goshen College, Goshen, Indiana, on November 24, 1964.
} 
does not circulate and tends to become damp is not recommended for valuable documents. A vault, in addition to being expensive to construct, makes an additional marking of materials necessary to designate that they are stored on other than the regular shelves. ${ }^{39}$ Most new buildings are fire-resistant, and documents can be made safe from theft without using a vault. Out of the forty-eight libraries from which reports were received, thirty-seven were considered fireresistant.

A church historical collection not only must be protected from physical enemies, but it must be guarded against theft, loss, and misuse by researchers and staff. No collection should be established without a set of rules to regulate and protect its contents. Each librarian will need to establish rules that will be pertinent to his particular collection. The following rules have been suggested by one archivist:

1. Register daily before using any materials.

2. Use no ink except in fountain pens.

3. Refrain from marking on any document or book.

4. Preserve the existing order of materials in file boxes and in drawers.

5. Handle documents at the assigned table space.

6. Open one container at a time.

7. Submit to inspection of briefcase, notebook, etc., before leaving the room.

8. Return all materials to the issue desk. $^{40}$

Staff members will need to be cautioned against unnecessary marking in the process of cataloging and classification. It seems that most materials have some library marking; the exception is the rare book or document. In this case

\footnotetext{
a Ibid.

${ }^{40}$ R. H. Land, "Defense of Archives Against Human Foes," American Archivist, XIX (April 1956), 132.
}

the marking is usually put on a slip of paper and inserted in the book like a bookmark. Thirty-seven of the fortyeight librarians returning questionnaires indicated that the materials in the church historical collection were marked with some distinguishing mark.

It is now possible to have important documents, correspondence, reports, periodicals, and other valuable materials in the collection microfilmed as an added protection against theft and loss. The report from one library indicated that all of its collection was on microfilm. Microfilming not only provides a copy of the original materials, it also makes the reproduction of needed information fairly easy. It is possible to have the paper issued by the library's church microfilmed with the assistance of the American Theological Library Association; however, a certain number of purchasers of the microfilm must be assured before the work is done. This not only gives the church historical collection the periodical on microfilm, it assures other copies in other libraries.

Books and bound periodicals cause little storage problem, for they can be shelved on regular library shelving. It is the manuscript, single documents, pictures, audio-visual materials, pamphlets, tracts, bulletins, and other miscellaneous printing that create the storage problem. Steel files of both legal and letter size are often used for the storage of correspondence, pictures, and single documents. The trend indicated by the questionnaire showed that pamphlet files stored on regular library shelving were most frequently used for reports, minutes, pamphlets, and other loose material. Often these files lie horizontally instead of standing vertically on the shelves. A few librarians had mounted single sheets on a protective backing and had them bound as a book. The following statistics show the responses on the questionnaires: twenty-one had materials 
filed in drawers, twenty-eight stored material in pamphlet files on regular library shelving, six mounted single sheets and had them bound, and seven used other methods of storage. This seven included storage in labeled boxes, locked cupboards, manila envelopes, and document boxes (Fiberdex) that lie flat on the shelves.

Many methods and materials for preservation are available. One might conclude, however, that the need is for these many materials to be used to protect the church historical collections against loss.

\section{Circulation and Control}

The reasons for collecting any body of material are not only to preserve it, but also to make it accessible for research and study. The church historical collection provides the raw material for histories, biographies, and various studies relating to the denomination, its people, and its organizational programs. To permit these studies to be made, the collection must be available to students and researchers. While most libraries have some restrictions on the use of the historical collection, the questionnaire showed that the materials were readily available for study. Of the forty-eight libraries, the collections in forty-five were open to anyone doing serious research. Users included church leaders, faculty members, students enrolled at the college, church members, and nonchurch affiliated researchers.

In thirty-three of the forty-eight libraries, users were allowed to take some of the material from the historical collection outside of the library, usually on a regular two-week loan. The materials allowed to leave the library were usually books of which there were at least two copies in the collection or books that could be replaced. Documents, minute books, reports, pictures, correspondence, etc., usually had to be used in the room of the collection. Sometimes the donor will restrict the use of his papers and personal items, such as diaries and date books, until after his death. Confidential material should be guarded against the simply curious person. Personal problems, for example, may be pointed out in a piece of correspondence, and this knowledge may bring harm to the reputation of the individual involved if it is available to anyone who is looking for a story. One librarian uses an application form to be filled out by all who wish to use the collection. This form asks for a statement of the purpose of the research. This in a measure limits the use of the collection to those engaged in serious study. Some librarians allowed nonbook materials to be used only under supervision; others provided locked carrels where such material could be used.

In some cases materials are provided to the public or to scholars on an interlibrary loan basis. This is usually a month loan, but one library will loan material indefinitely to anyone engaged in a long piece of research with the understanding that the material can be called in if it is needed.

One of the problems facing the librarian in charge of a church historical collection is the need for indexes for the church paper. This is necessary if the collection is to be of most value for research and study. Some of the libraries visited for this study have made an attempt to solve this problem. The approaches to the problem have been different in each case. One school requires each student in the denominational history class to index one volume of the church paper. They use three by five inch cards and make entries (following Reader's Guide style) for all titles, names of those writing and/or written about, and subject cards if the subject is easily discernible. These cards are turned in to the librarian in charge of the collection who checks the work on that volume for errors. While this process is not 
completely satisfactory, it does provide a degree of access to the material. ${ }^{41}$ Another school hires a student to work on indexing, while another college has each researcher write down the title, author, and subject of the material used in his research. This information is then put on cards, and the cards are filed as a partial index.

An attempt at indexing a number of denominational papers has been made by the publishers of the Minister's Periodical Index (Albert M. Wells, Executive Secretary, Box 1542, Sterling, Colorado). This work has not proven to be scholarly or always accurate, but some librarians have found it a help if it indexed their particular church paper.

The time, staff, and expense involved in indexing have made this an impossibility for many colleges. It is an area that needs attention, however, if the church historical collections are to be of most value.

The responding forty-eight librarians indicated that usually the church historical collection is under the supervision and control of the regular library staff. In thirty-four libraries of the forty-eight this was so. Some libraries have one person designated to work in the archives. It is not always a librarian, but a historian or someone who has worked years at the college in another capacity. In only five of the forty-eight libraries was the person in charge of the collection a trained archivist. One or two more had attended a workshop for archivists such as the four- to six-week session offered by the American University in Washington, D.C.

The last question on the questionnaire asked for the total number of volumes in the collection with a breakdown of books, periodicals, and single documents. No attempt has been made to tabulate the answers. The reason for this is evi-

41 Stated by Delena Goodman in an interview with Lois Luesing at Anderson College, Anderson, Indiana, on December 8, 1964. dent by the following answers: "Too many to count," "Can't estimate," "A great mass of material," "Large number," "Thousands," "Not sufficiently organized to count." Those giving figures ranged from a total of 250 pieces in one collection to fifty thousand single documents, twelve thousand books, one thousand bound periodicals, two hundred current periodicals, four thousand pictures, and three hundred spools of microfilm in another. From the questionnaires, one might deduce that church historical collections housed in liberal arts colleges range from the smallest unorganized body of materials that came together solely by chance to the large, highly organized, complex collection that has been systematically collected.

The method of circulation and control of the church historical collection must be established to fit the needs of the individual institution. If the materials are properly cataloged and classified, the problems would appear to be less complicated. To make the collection available and comparatively easy to use is a worthwhile goal for any library.

\section{Conclusions}

The college library administration that makes an attempt to collect, catalog, house, and administer a church historical collection needs funds, staff, and storage space in addition to the regular library needs. From this study one could easily conclude that those librarians who are actively involved in building and maintaining a church historical collection and who have materials adequate and accessible for research are relatively few in number. Of the fifty-six librarians from whom questionnaires were received, eight had no cataloged collection; and of the forty-eight who had collections, several were not doing much with the collections in their care.

Church historical collections are as varied as the groups which sponsor them. They vary in what they include, how 
they are cataloged, and how they are made available for research. It is quite evident from the questionnaire sent out that many collections have been built by coincidence. The library simply houses the materials which happen to come its way. These collections are chiefly minutes, official directories, books, periodicals, and other material published by the denomination. Those comparatively few libraries that include audio-visual materials, correspondence, and pictures are those where an organized effort has been made to collect such material. One would conclude that college librarians having the responsibility of church historical collections need to exert more effort to collect the various types of material that pertain to their individual denominations.

This study has not been concerned with the cost of such a collection; perhaps some study should be made to determine who pays for the church historical collection. Does the college assume all the cost, or does the denomination share the expenses of acquisition, cataloging, and staff?

One might conclude in both the areas of cataloging and of means to insure preservation that the greatest problem is the lack of either of these activities. While most collections are at least partially cataloged, it appears that many have nonbook materials that are not adequately cataloged. If the ideal is to have each piece and each document fully cataloged, ${ }^{42}$ each library with such a collection needs to make a concerted effort in this direction. Since the aim is to make the materials as available as possible, this should become more a reality than an ideal.

It was noted earlier that of the fortyeight libraries only fifteen treat their books for preservation and only nine their single documents. It would seem

\footnotetext{
42 Stated by Nelson Springer, in an interview with Lois Luesing at Goshen College, Goshen, Indiana, on November 24, 1964.
}

that this type of work is seriously neglected. The church historical collection often has the only existing copies of valuable research materials; thus, the importance of using some methods of preservation is great. It would be most helpful if the person in charge of the collection would become familiar with some of the methods and materials of preservation used by rare book librarians.

Storage problems are faced by many librarians. Since this collection could grow to large proportions, adequate space should be provided in any new library building. Proper control facilities should be planned with the necessary safeguards against theft, loss, and fire. Locked files and cabinets, work space, and adequate shelving should be included.

It can be concluded that the church historical collections in liberal arts colleges are readily available for study and research. The questionnaire and visits showed that an attitude of helpfulness was evident on the part of the library staffs. Every effort should be made to continue to have the materials as easily available as possible.

It has also been noted that the responsibility for the church historical collection usually lies with the regular library staff. Few are adequately trained for the work they are required to perform. If the person designated to care for the collection could attend an archival workshop many valuable benefits would accrue. If this is not possible a visit to a library with an established collection could be of much value. Some effort should be made to give the individual working with the materials some guidance in cataloging, housing, etc. No one enjoys revising work already poorly done, so some guidance at the beginning could eliminate the necessity for much of this later work. If the individual

\footnotetext{
(Continued on page 317)
} 
Contents: v.1,pt.1, Do roku 1454. 759p., zł.155; v.1,pt.2, 1454-1795. 399p., zt.86.

These two parts make up Volume I of what is to be a three-volume bibliography of Polish history from earliest times to 1944. The first section of part one is a general guide to bibliographic and reference aids, methodology, historiography, archives and libraries, and auxiliary studies; it is followed by bibliography of Polish history arranged by periods to 1454 , with appropriate subdivisions. Volume I, part 2, continues the period sections to 1795 . (Volume II will deal with Polish history to 1918, and Volume III that of the years following.) While coverage extends to such subjects as statistics, economics, and sociology, the bibliography is meant to be selective rather than exhaustive. Both books and periodical materials are included; the great bulk of entries is, understandably, in Polish. There are some brief annotations and cross references; items are numbered; and an author index is promised.-E.S.

Répertoire méthodique de lhistoire moderne et contemporaine de la France. v.8, Années 1907, 1908 et 1909. Paris: Editions du Centre National de la Recherche Scientifique, 1965. 241p. $20 \mathrm{~F}$.

After an unusual number of delays and vicissitudes this volume, edited from the original research of Pierre Caron and his associates, appears to fill the gap in the series (Guide V235) so that it now offers consecutive coverage for the 18981913 period. The classified arrangement with indexes of authors and persons and of places is consistent with that of the previously published volumes.-E.S.

\section{CHURCH HISTORICAL COLLECTIONS . . .}

(Continued from page 303 )

working with the collection is not a professional librarian, basic rules of filing, cataloging, classification, and preservation must be mastered.

One of the most important things would seem to be to establish a set of rules and organizational procedures to be followed. No collection should be allowed, like Topsy, simply to grow. A mass of unorganized materials is of little value to anyone.

Patrick Henry once said, "I know of no way of judging of the future but by the past." 43 If this be true, it can be concluded that if the various church bodies are to progress in the days to come, they must know their history and heritage. A collection of church historical materials is essential to such knowledge.

4 Patrick Henry, "American Liberty," Great Americans Speak ...., ed. by F. C. Packard (New York: Scribner, ${ }_{[}^{1951_{]}}$), p. 2.

\section{JUNIOR COLLEGE . . .}

\section{(Continued from page 266)}

The people who met in May recommended to their respective boards that a continuing joint committee of AAJC and ALA be established to give leadership to such projects and that some full-time staff services be made available to the committee.

This presentation started with an emphasis upon the importance of communication in the learning process. The events just reported lead to the happy conclusion that communication is improving between professionals who have somewhat different responsibilities on the campus but a common interest in facilitating the learning process through effective and suitable library services.

We can talk to each other. We can listen to each other. We have a basis for understanding. And it is in that kind of climate that we move into this era with the conviction that what we shall do is difficult, but more important, it is essential, and it is time it was done. 